Bull. Fac. Agric., Cairo Univ., 70: 219-228 (2019)

\title{
ASSESSMENT OF RESISTANCE TO PINK STEM BORER AND APHID INFESTATION IN SWEET SORGHUM CULTIVARS AND THEIR PRODUCTIVITY AND TECHNOLOGICAL TRAITS UNDER FOUR SOWING DATES
}

(Received:23.9.2019)

\author{
By \\ R. S. Besheit, Samar A. M. Helmy and S. M. I. Bachoosh \\ Sugar Crops Research Institute, Agriculture Research Center, Giza, Egypt.
}

\begin{abstract}
Two field trials were conducted at El-Fayoum Governorate, Tamia destrict $\left(29^{\circ} 17 \mathrm{~N}, 30^{\circ} 53 \mathrm{E}\right)$, Egypt, during summer 2017 and 2018 seasons, to evaluate the susceptibility to two dangerous insect pests i.e. pink stem borer (Sesamia cretica) and corn leaf aphid (Rhopalosiphum maidis) under natural infestation, the productivity, quality of ten sorghum cultivars (Brands, Dale, Honey, Leoti, Planter, Rex, Rio, Tracy, Umbrella and Williams) sown under four sowing dates (Mid. April, May, June and July). The results of the separate and combined seasons indicated that all noticeable signs of damage parameters of pink stem borer and corn leaf aphid significantly increased gradually with delaying sorghum sowing. Sowing in mid June or July suffered more damage to both insects as compared with early sowing. Regarding the noticeable damage signs. It significantly differed among the ten sweet sorghum cultivars, where, Rio, Dale and Williams cultivars recorded the least infestation which gave evidence that those cultivars were relatively tolerant to both insects, while, Honey and Umbrella cultivars recorded the highest infestation features. Quality traits (TSS, Sucrose\% and reducing sugars) insignificantly differed among the four sowing dates and cultivars. Juice Extraction Percentage (JEP), glucose ratio (GR) and juice purity significantly differed among the four sowing dates. The values of JEP and juice purity decreased gradually as sowing date delayed, while, GR recorded the lowest value on May sowing as compared with other three sowing dates. On the contrary, Syrup Extraction Percentage (SEP), Total Fermentable Sugars (TFS) and Fiber \% were insignificantly differed among the four sowing dates. Great variation has been detected for all processing parameters among the tested cultivars except TFS\%. The results also showed that all productivity traits were significantly decreased as sowing date delayed to reach its minimum at July sowing. Productivity clarified that average stripped stalk wt., stripped stalk, juice, syrup and ethanol yields significantly differed among the tested cultivars (except forage yield). Rio cultivar yielded the highest productivity traits, while, Honey cultivar exhibited the lowest ones. The variation observed among the tested sorghum cultivars for all studies traits were markedly related to the tolerance and susceptibility of used the tested cultivars to pink stem borer and corn leaf aphids which measure by many constant parameters as discussed previously. In general, Rio, Dale and Williams sorghum cultivars sown on mid April sowing dates exhibited the higher productivity and quality traits and the lower damage signs or to some extend characterized as relatively tolerance to pink borer and corn leaf aphid infestation.
\end{abstract}

Key words: sweet sorghum,resistance, stem borer, sowing dates.

\section{INTRODUCTION}

Sorghum (Sorghum bicolor (L.), Moench) is one of the important food, Feed and fodder crops in arid and semi arid regions of the world (Shoemaker and Bransby, 2010). The sweet stalk sorghum possesses sweet juice in their stalk tissue. Further, the ability of sweet sorghum to adapt to drought, saline soil and water logging is very high. Moreover, short growing period, low water requirements, lower cost of cultivation compared with sugarcane and sugarbeet (Audilakshmi et al., 2010 and Xin and Wang, 2011). Sweet sorghum is a multipurpose crop due to its capacity to provide renewable energy product (ethanol), industrial commodities and concentrated syrup with distinctive flavour, forage and some varieties could used for refining sugar production (Allam et al., 2001; 
Almodares et al., 2009 and Aman, 2010).

Sorghum plants in Egypt are severely attacked by different species of lepidopteron insects. The most prevalent and dangerous is pink stem borer, Sesamia cretica (Led.). This insect attacks sorghum plants after emergence devours the whorl leaves and kills the growing meristem tissue, causing dead heart (Mailafiya and Degri, 2012). The insect is also capable to damage older plants and excavating tunnels into the stem. This insect greatly and negatively affected stalk, grain, forage yields, juice quantity and quality (Abd El-Razek et al., 2014; Amer and Besheit, 2016 and Besheit and Mekdad, 2016). Moreover, stem borers are difficult to control largely because of nocturnal habits of adult moth and the cryptic feeding behavior of the larvae, which resides inside the plant stem. There is scanty information on the resistance of stem borer in sweet sorghum; therefore, efforts will largely focus not only on high yielding stems but also to select tolerance varieties.

Furthermore, among the sap sucking pest insect are aphids (Hemiptera: Aphididae) is corn leaf aphid (Rhopalasiphum maidis Fitch) (Blackman and Eastop, 2000; Amin et al., 2013 and Aly and Besheit, 2014). Aphids cause direct damage as phloem feeders, and inject a toxin which destroy the chloroplast membranes and indirect damage as plant virus vectors and secreting honey dew which become suitable media for sooty moulds (Helmi and Rashwan, 2013)

In addition, great attention have been paid by many workers to the importance of sowing date and cultivars on quantity and quality of sweet sorghum, and proper cultivars in suitable sowing date which perform high yielding ability, chemical and technological characteristics (ElRawy et al., 2013; Djodda et al., 2013; El Geddawy et al., 2014; Amer and Besheit, 2016 and Besheit and Mekdad, 2016).

This work aimed to assess the productivity and quality of ten sweet sorghum cultivars and its sensitivity to pink stem borer and corn leaf aphid infestation under four sowing dates at ElFayoum Governorate.

\section{MATERIALS AND METHODS}

To evaluate the productivity, quality and susceptibility to the most dangerous insect pest pink stem borer [Sesamia cretica Led., Lepidoptera, Noctuidae] and corn leaf aphid of ten sorghum cultivars namely Brands, Dale, Honey, Leoti, Planter, Rex, Rio, Tracy,
Umbrella and Williams sown under four sowing dates on mid April, May, June and July, two field trials were conducted in Khalifa Youns, Tamea district El-Fayoum Governorate $\left(29^{\circ} 17\right.$ N, 30 53 E), Egypt during 2017 and 2018 seasons. Split plot design with four replicates was used. Sowing dates occupied the main plots, while, cultivars were randomly distributed in the sub plots units. Plot size was $21 \mathrm{~m}^{2}$ (1/200 Fed.), consist of 5 rows, $7 \mathrm{~m}$ long and $60 \mathrm{~cm}$ apart within inter row spacing of $25 \mathrm{~cm}$.

Seedlings were thinned at two plants per hill after 3 weeks from sowing date. Nitrogen $(60 \mathrm{~kg} \mathrm{~N} / \mathrm{fed}$.) was applied in three equal doses one third after thinning directly. The second and the third doses were added after 7 and 10 weeks from planting, respectively. Further, calcium super phosphate $\left(15.5 \mathrm{P}_{2} \mathrm{O}_{5}\right)$ at the rate of 100 $\mathrm{kg} /$ fed. was applied during land preparation. All other cultural procedures were carried out as usual. Application of insecticides was excluded throughout the whole season. Harvest was carried out at the ripe stage in both seasons. The three middle guarded rows were used to determine millable stalk yield. Twenty five stripped stalks were taken randomly from each plot and immediately crushed through 3 roller lab. The raw juice was filtered and weight to calculate juice extraction percentage (JEP) and juice yield/fed. from the following equation:

$\mathrm{JEP}=($ Juice weight/stripped stalks weight $) \times 100$ Juice yield $($ ton/fed. $)=($ stripped stalk yield $\times$ JEP $) / 100$ Three $\mathrm{kg}$ juice from each sample was used for syrup manufacture. Syrup extraction percentage (SEP) and syrup yield (ton/fed.) were calculated from the following equations: $S E P=$ (Syrup weight / Juice weight $) \times 100$

Syrup yield $=$ Juice yield $\times$ SEP

Theoretical ethanol yield (EtOH) was calculated according to Smith and Buxton (1993)

Juice quality including Total Soluble Solids (TSS or Brix), Sucrose \% (Pol), reducing sugars and purity percentages were determined according to the methods of Meade and Chen (1977).

Infestation parameters:

1. Dead heart percentage was calculated before thinning according to Maareg et al. (1993).

2.Infested stalk percentage (Infestation incidence) $=$ No. of bored stalks / No. of examined stalks $\times 100$.

3.Infested joints percentage (Infestation intensity) $=$ No. of infested joints / No. of examined joints $\times 100$.

4.No. of larvae / 25 plants. 
5.No. of holes / 100 joints.

6.Tunnels percentage.

7.Average tunnel length.

8.No. of aphids /plant.

9.No. of infested plant / 25 plants.

Percentage data were transformed by Arcsin units before statistical analysis. Statistical analysis was performed according to the technique of analysis of variance (ANOVA) of split plot in Randomized Complete Block Design as published by Gomez and Gomez (1984), using MSTATE statistical package (Mstate-C). Treatment means were compared using L.S.D. at $5 \%$ level of probability.

\section{RESULTS AND DISCUSSION}

\subsection{Damage parameters}

The most destructive insect pest that attack sorghum genus is pink stem borer (Sesamia cretica Led., Lepidoptera, Noctuidae). It causes considerable damage along the whole plant cycle in both leaf and stalks (Djodda et al., 2013; Amer and Besheit, 2016 and Besheit and Mekdad, 2016). This damage is measured by many constant parameters expressed as dead heart $(\mathrm{DH})$, infested bored stalks percentage (infestation incidence), infested bored joints percentage (infestation intensity), No. of larvae $/ 25$ plant, No. of holes/ 100 joints, No. of tunnel $\%$ plants and average tunnel length $\mathrm{cm}$. Meantime, corn leaf aphid (Rhopalosiphum maidis Fitch) on sorghum leaves is a serious sap sucking insect pest. The combined data for 2017 and 2018 seasons (Table 1) and the separate seasons (not presented) that illustrate all noticeable sign of damage parameters are shown in Table (1). These parameters increased gradually and significantly with delaying sorghum sowing. Plants at sowing during June and July suffered more damage by borers as compared with sowing during April and May. Such effect may be due to the fact that plantations during April and May are more favorable in terms of temperature, day length and light intensity, than those prevailing during June and July, especially in the seedling stage and hence greatly and negatively reflected on yields, quality and technology traits (AbdelGawad, 1981). These findings are in general agreement with those of Almodares et al. (1994); and Besheit et al., (1996).

Regarding corn aphid infestation, the combined data in Table (1) stated that corn aphid infestation took the same tendency as pink stem borer with respect to sowing date. Gradual and significant increase in aphid population density/ plant and No. of infested plant percentage with delaying sowing up to June and July. These results are in an accordance with those of Munson et al., 1993.

Combined data across 2017 and 2018 seasons (Table 1) and the other years (not presented) indicated that dead heart infestation significantly differed among the tested ten sweet sorghum cultivars, where, Williams, Leoti, Dale, Brands, Rio and Rex recorded the lowest infestation. Honey cultivar exhibited the highest dead heart. Regarding the other noticeable damage signs i.e. infestation incidence, infestation intensity, No. of larvae/ 25 plants, No. of holes/ 100 joint, No. of tunnel \% and tunnel length $\mathrm{cm}$, Rio cultivar declared the lowest values of all damage parameters, followed by Dale and Williams cultivars. These findings gave evidence that those cultivars are relatively tolerant to pink stem borer infestation. On the other hand, the other cultivars recording high damage parameters could be considered more sensitive to infestation. The highest susceptibility cultivars were Honey and Umbrella which recorded the highest infestation parameters. These findings gave evidence that nane of the used cultivars were immune to pink stem borer, $S$. cretica as shown in other years. The variation among the used cultivars may be due to genetic causes and / or the interaction between the genotypes and environment at conditions prevailing during the four sowing dates. These findings are in harmony with those of Mailafiya and Degri, 2012; El-Rawy et al., 2013 Nuessly et al., 2013; Salman et al., 2014 and Besheit and Mekdad, 2016).

Combined data across 2017 and 2018 (Table 1) cleared that No. of corn aphid/ plant and No. of infested plants percentage were substantially differed among the ten sorghum cultivars. Further, No. of individuals/ plant was fluctuated between 241.84 for Rio cultivar and 398.42 for Honey cultivar and No. of infested plants percentage was range in 3.59 and 6.51 for the same cultivars (Table 1). In general, data cleared that no cultivars appeared to have absolute immunity towards this destructive insect pest but those cultivars showed some degree of tolerance and susceptibility to some insect attack. 


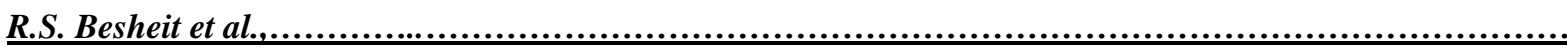

Table (1): Influence of sowing dates and cultivars on borer and aphid infestation

(combined over 2017 and 2018 seasons).

\begin{tabular}{|c|c|c|c|c|c|c|c|c|c|}
\hline \multirow[b]{2}{*}{ Factors } & \multicolumn{7}{|c|}{ Borer infestation } & \multicolumn{2}{|c|}{ Corn leaf aphids } \\
\hline & 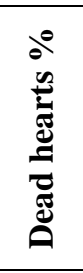 & 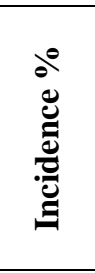 & 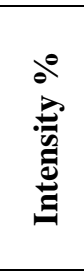 & 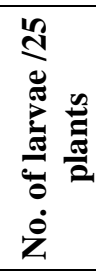 & 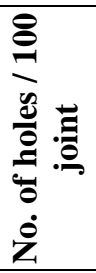 & $\underset{\Xi}{\stackrel{d}{\Xi}}$ & 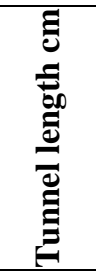 & 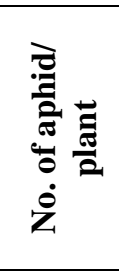 & 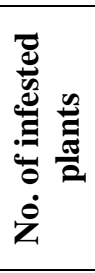 \\
\hline \multicolumn{10}{|l|}{ Years (Y) } \\
\hline 2017 & 6.36 & 12.04 & 4.44 & 3.74 & 9.33 & 11.77 & 6.30 & 264.77 & 3.90 \\
\hline 2018 & 7.42 & 15.99 & 6.67 & 5.22 & 13.60 & 13.87 & 7.05 & 377.78 & 6.37 \\
\hline Sign. & $* *$ & $* *$ & $* *$ & $* *$ & $* *$ & $* *$ & $* *$ & $* *$ & $* *$ \\
\hline L.S.D. $5 \%$ & 0.51 & 1.10 & 0.58 & 0.35 & 0.73 & 0.99 & 1.05 & 15.83 & 0.52 \\
\hline \multicolumn{10}{|c|}{ Sowing dates $(\mathbf{S})$} \\
\hline 15 April & 5.99 & 12.81 & 4.25 & 4.60 & 7.96 & 8.94 & 4.45 & 289.50 & 3.89 \\
\hline 15 May & 6.47 & 12.53 & 5.64 & 4.36 & 9.35 & 10.86 & 5.37 & 273.05 & 3.67 \\
\hline 15 June & 7.01 & 14.98 & 5.97 & 4.48 & 14.72 & 15.91 & 7.89 & 345.69 & 6.59 \\
\hline 15 July & 8.09 & 15.76 & 6.38 & 4.47 & 13.85 & 15.57 & 9.01 & 376.84 & 6.41 \\
\hline Sign. & $* *$ & $* *$ & $*$ & N.S & $* *$ & $* *$ & $* *$ & $* *$ & $* *$ \\
\hline L.S.D. $5 \%$ & 0.51 & 0.84 & 0.46 & - & 0.51 & 1.43 & 1.27 & 39.54 & 0.31 \\
\hline \multicolumn{10}{|l|}{ Cultivars (C) } \\
\hline Brands & 6.23 & 14.83 & 5.65 & 4.09 & 11.85 & 13.42 & 6.17 & 338.00 & 5.50 \\
\hline Dale & 6.17 & 11.42 & 4.25 & 3.67 & 10.70 & 11.26 & 4.70 & 282.75 & 4.75 \\
\hline Honey & 7.94 & 17.87 & 7.62 & 6.42 & 13.92 & 16.42 & 10.10 & 398.42 & 6.51 \\
\hline Leoti & 6.09 & 12.71 & 4.96 & 3.84 & 10.61 & 11.59 & 6.15 & 312.17 & 5.09 \\
\hline Planter & 7.74 & 14.65 & 6.03 & 4.76 & 12.23 & 13.67 & 7.80 & 322.75 & 5.25 \\
\hline Rex & 6.71 & 14.41 & 5.60 & 4.51 & 11.17 & 12.76 & 6.47 & 311.67 & 4.92 \\
\hline Rio & 6.62 & 9.73 & 3.78 & 2.50 & 8.05 & 8.92 & 3.05 & 241.84 & 3.59 \\
\hline Tracy & 7.76 & 15.33 & 6.06 & 5.17 & 12.58 & 14.26 & 8.28 & 348.26 & 5.51 \\
\hline Umbrella & 7.59 & 16.75 & 6.71 & 5.84 & 13.39 & 15.34 & 8.70 & 369.59 & 5.42 \\
\hline Williams & 6.08 & 12.48 & 4.94 & 4.01 & 10.19 & 10.59 & 5.34 & 287.25 & 4.84 \\
\hline Sign. & $*$ & $* *$ & $* *$ & $* *$ & $* *$ & $* *$ & $* *$ & $* *$ & $* *$ \\
\hline L.S.D. 5\% & 0.64 & 1.20 & 0.99 & 1.42 & 0.94 & 2.18 & 0.87 & 59.95 & 1.20 \\
\hline \multicolumn{10}{|l|}{ Interactions } \\
\hline YxS & $* *$ & $* *$ & N.S & N.S & $* *$ & N.S & N.S & $* *$ & N.S \\
\hline YxC & $* *$ & $* *$ & $* *$ & $* *$ & $* *$ & $* *$ & $* *$ & $* *$ & $*$ \\
\hline $\mathrm{SxC}$ & $* *$ & $* *$ & $* *$ & $*$ & $* *$ & $* *$ & $*$ & $* *$ & N.S \\
\hline YxSxC & $* *$ & $* *$ & $* *$ & N.S & $* *$ & N.S & N.S & $* *$ & N.S \\
\hline
\end{tabular}

\subsection{Quality traits}

Combined results (2017 and 2018 seasons) of the total soluble solids (TSS), sucrose \% and reducing sugars insignificantly differed among the four sowing dates (Table 2). The results also cleared that the separate seasons were insignificant for sucrose and reducing sugars only, even so, the values of three quality traits were higher in 2018 than 2017 season.

With regard to cultivars effect on the three quality traits, the differences among the cultivars did not reach the level of significance for the three quality traits. These results gave evidence that quality traits were affected greatly by climatic change from year to another than genetic constituents. These results are corroborate those of Allam et al. (2001), AlLabbody et al., (2008), Amer and Besheit (2016) and Besheit and Mekdad (2016).

\subsection{Technological traits}

Results (Table 2) indicated that juice extraction percentage (JEP) was significantly 
Table (2): Influence of sowing dates and cultivars on quality and technological traits (combined over 2017 and 2018 seasons).

\begin{tabular}{|c|c|c|c|c|c|c|c|c|c|}
\hline \multirow[b]{2}{*}{ Factors } & \multicolumn{3}{|c|}{ Quality traits } & \multicolumn{6}{|c|}{ Technological traits } \\
\hline & $\begin{array}{l}0 \\
\mathscr{E} \\
\mathscr{E}\end{array}$ & $\underbrace{0}_{0}$ & 异 & $\begin{array}{l}0 \\
\frac{2}{b}\end{array}$ & $\frac{2}{\sqrt{2}}$ & 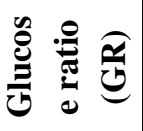 & $\stackrel{\Xi}{E}$ & D & $\sum_{i=1}^{0}$ \\
\hline \multicolumn{10}{|l|}{ Years (Y) } \\
\hline 2017 & 16.23 & 9.16 & 4.28 & 46.74 & 7.71 & 46.73 & 56.44 & 13.24 & 13.79 \\
\hline 2018 & 18.18 & 9.64 & 4.49 & 48.67 & 7.45 & 46.58 & 53.03 & 14.30 & 13.43 \\
\hline Sign. & $* *$ & N.S & N.S & $* *$ & N.S & N.S & $* *$ & N.S & N.S \\
\hline L.S.D. 5\% & 1.10 & - & - & 0.99 & - & - & 0.45 & - & - \\
\hline \multicolumn{10}{|c|}{ Sowing dates (S) } \\
\hline 15 April & 17.05 & 9.45 & 4.45 & 48.24 & 7.42 & 47.09 & 55.47 & 13.89 & 13.73 \\
\hline 15 May & 17.16 & 9.75 & 4.34 & 48.15 & 7.48 & 44.51 & 56.86 & 14.10 & 13.49 \\
\hline 15 June & 17.30 & 9.21 & 4.29 & 47.56 & 7.61 & 46.58 & 53.59 & 13.50 & 13.54 \\
\hline 15 July & 17.35 & 9.19 & 4.47 & 46.89 & 7.89 & 48.63 & 52.97 & 13.66 & 13.68 \\
\hline Sign. & N.S & N.S & N.S & $*$ & N.S & $* *$ & $* *$ & N.S & N.S \\
\hline L.S.D. 5\% & - & - & - & 1.17 & - & 0.92 & 0.63 & - & - \\
\hline \multicolumn{10}{|l|}{ Cultivars (C) } \\
\hline Brands & 16.84 & 9.38 & 4.11 & 46.76 & 7.23 & 43.82 & 55.74 & 13.51 & 14.77 \\
\hline Dale & 17.75 & 9.84 & 4.11 & 49.74 & 6.57 & 41.77 & 55.56 & 13.94 & 12.83 \\
\hline Honey & 17.04 & 8.31 & 4.57 & 44.89 & 7.97 & 54.09 & 48.78 & 13.36 & 14.33 \\
\hline Leoti & 17.35 & 9.60 & 4.29 & 48.45 & 9.17 & 44.69 & 55.30 & 13.87 & 12.85 \\
\hline Planter & 17.30 & 9.06 & 4.58 & 47.43 & 8.58 & 50.05 & 52.36 & 14.14 & 13.76 \\
\hline $\operatorname{Rex}$ & 16.74 & 9.80 & 4.15 & 47.31 & 7.19 & 42.35 & 58.55 & 13.93 & 14.28 \\
\hline Rio & 17.36 & 9.55 & 4.44 & 48.14 & 7.55 & 46.49 & 55.00 & 13.98 & 13.02 \\
\hline Tracy & 17.87 & 9.39 & 4.81 & 47.01 & 7.14 & 51.23 & 52.57 & 13.68 & 13.78 \\
\hline Umbrella & 16.84 & 9.32 & 4.67 & 48.68 & 8.19 & 50.11 & 55.39 & 13.49 & 13.36 \\
\hline Williams & 17.03 & 9.79 & 4.16 & 48.68 & 6.23 & 42.49 & 57.51 & 13.95 & 13.07 \\
\hline Sign. & N.S & N.S & N.S & $* *$ & $*$ & $* *$ & $* *$ & N.S & $* *$ \\
\hline L.S.D. 5\% & - & - & - & 1.59 & 0.42 & 1.28 & 1.05 & - & 0.48 \\
\hline \multicolumn{10}{|l|}{ Interactions } \\
\hline YxS & N.S & N.S & N.S & $*$ & N.S & $* *$ & $*$ & N.S & N.S \\
\hline YxC & $*$ & N.S & N.S & $* *$ & N.S & $* *$ & $* *$ & N.S & $*$ \\
\hline $\mathrm{SxC}$ & N.S & N.S & N.S & $* *$ & N.S & $* *$ & $* *$ & N.S & $*$ \\
\hline YxSxC & $*$ & N.S & N.S & $* *$ & $*$ & $* *$ & $* *$ & N.S & $*$ \\
\hline
\end{tabular}

differed among the four sowing date. The values of JEP were decreased gradually as sowing date delayed from April to July. On the contrary, syrup extraction percentage was insignificantly affected by sowing date (Table 2).

Juice purity and glucose ratio (GR) were markedly affected by sowing dates where, a gradual decrease in purity have been observed as sowing date delayed. Results also cleared that sowing in May significantly recorded the lowest GR value. Similar findings were reviewed by Besheit et al. (1996) and Al-Labbody et al. (2008).
Sowing dates insignificantly influenced the total fermentable sugars and stalk fiber percentage (Table 2). Such effect may be due to the insignificant effect on both sucrose and reducing sugars discussed before. Further, environmental factors prevailing in each season did not affect both traits. Insignificant differences were found between the two seasons in sucrose, reducing sugars, total fermentable sugars and fiber percentage as shown in Table (2).

Great variations in all processing parameters have been detected among the tested cultivars 
except the total fermentable sugars percentage, where, slight differences among cultivars were observed (Table 2). Dale, Leoti, Umbrella and Williams with insignificant differences among them recorded the highest JEP. However, Honey followed by Brands exhibited the lowest JEP.

Regarding syrup extraction percentage (SEP), results in Table (2) indicated that SEP values ranged between $6.23 \%$ with Williams cultivar to $9.17 \%$ with Leoti cultivar.

Purity and glucose ratio (GR) were significantly different among the tested sorghum cultivars. The highest purity $(58.55 \%)$ was in Rex cultivar followed by Williams (57.51\%), corresponding to the lowest GR values recorded by the same mentioned cultivars, On the other hand, the lowest purity (48.78\%) and the highest GR value $(54.09 \%)$ were that of Honey cultivar. The reduction of purity values and the increase in GR values make sorghum juice potentiality more suitable for syrup industry and energy production, via decreasing operational problems for sugar crystallization (Besheit et al., 2000; Al-Labbody et al. 2008; Amer and Besheit, 2016 and Besheit and Mekdad, 2016).

The combined results of 2017 and 2018 seasons and other seasons (not presented) demonstrated that total fermentable sugars (TFS) was insignificantly affected by the tested sweet sorghum cultivars (Table 2). Such effect may be due to the insignificance of the tested sorghum cultivars difference between sucrose and reducing sugars.

Otherwise, significant variations in fiber \% have been observed among the tested cultivars. Their values fluctuated between $12.83 \%$ and $12.85 \%$ for Dale and Leoti and $14.77 \%$ and $14.28 \%$ for Brands and Rex cultivars, respectively. The other cultivars were between these limits.

\subsection{Yields}

\subsubsection{Average stripped stalk weight per plant and stripped stalk yield/ feddan}

Combined results (Table 3) indicated that average stripped stalk weight/ plant and stripped stalk yield/ fed. were significantly influenced by sowing dates. Sowing in May exhibited the highest average stalk weight/ plant and stalk yield/ fed. followed directly by sowing in April (Table 3). Otherwise, delaying sowing significantly reduced both traits. These results gave evidence that growing conditions as sowing delayed up to harvest are apparently unfavorable in terms of temperature, day length and light intensity (Abdel-Gawad, 1981).
Moreover, higher values of various noticeable signs of pink stem borer associated with late sowing as mentioned before or with other words to the high borer insect attack sweet sorghum with delay sowing in comparison with early sowing. These findings are in full agreement with those of Almodares et al. (1994), Besheit et al., (1996) and Al-Labbody et al., (2008).

Combined results across 2017 and 2018 (Table 3) clarified that stripped stalk yield/ fed. significantly differed among the tested cultivars. Rio cultivar exhibited the highest stripped stalk yield/ fed. (27.47 ton) followed by Dale, Rex, Williams and Leoti cultivars (without significant differences), moreover, Honey cultivar yielded the lowest stripped stalk yield/fed. (21.86 ton). The observed variation in cultivars productivity was associated obviously with the recorded average stripped stalk wt (Table 3). Furthermore the variation among the studied cultivars with respect to both traits may be of genetic causes and/or due to interaction between cultivars and sowing dates (Galal et al., 2002 and Mailafiya and Degri, 2012). Moreover, the degree of damage caused by pink stem borer and corn aphid significantly differed among the used cultivars and was greatly affected both trait as mentioned before. The obtained results are in line with those of Al-Labbody et al. (2008), ElGeddawy et al. (2014); Amer and Besheit (2016) and Besheit and Mekdad (2016) who stated marked differences among sorghum cultivars with regard to stalk yield and stalk components.

\subsubsection{Forage yield}

Forage yield is the contribution of green leaves, tillers, branches and inflorescences at harvest time. This component is very important due to the shortage of green feed during summer period, where, forage yield (f) insignificantly differed between both seasons over the sowing dates and cultivars. Meantime, combined results across of both seasons (Table 3) indicated that forage yield gradually and significantly decreased with delaying sowing from April which recorded the highest forage yield up to July which recorded the lowest forage yield. Such effect may be due to severe damage caused by pink stem borer and corn aphid accompanied delaying sowing. These results are in agreement with those reported by Almodares et al. (1994) and Besheit et al. (1996) who stated that May sowing exhibited the highest forage yield/ fed. as compared with April sowing or June sowing. 
Table (3): Effect of sowing dates and cultivars on productivity traits of sweet Sorghum (combined over 2017 and 2018 seasons)

\begin{tabular}{|c|c|c|c|c|c|c|}
\hline Factors & 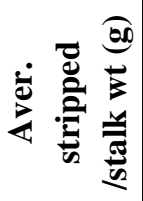 & 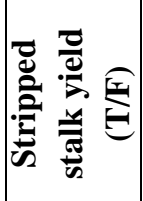 & 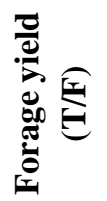 & 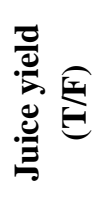 & 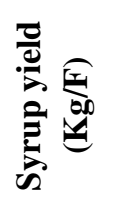 & 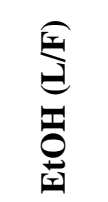 \\
\hline \multicolumn{7}{|l|}{ Years (Y) } \\
\hline 2017 & 754 & 23.52 & 7.33 & 11.07 & 850.3 & 782.2 \\
\hline 2018 & 1100 & 25.83 & 7.52 & 12.67 & 941.6 & 968.1 \\
\hline Sign. & $* *$ & $* *$ & N.S & $*$ & $* *$ & $* *$ \\
\hline L.S.D. 5\% & 89 & 1.67 & - & 0.60 & 86.40 & 67.1 \\
\hline \multicolumn{7}{|c|}{ Sowing dates $(S)$} \\
\hline 15 April & 1055 & 25.93 & 8.12 & 12.93 & 957.4 & 937.1 \\
\hline 15 May & 1127 & 26.89 & 7.64 & 12.95 & 968.3 & 943.0 \\
\hline 15 June & 785 & 23.73 & 7.58 & 11.29 & 859.5 & 873.2 \\
\hline 15 July & 741 & 22.17 & 6.38 & 10.39 & 798.6 & 747.5 \\
\hline Sign. & $* *$ & $* *$ & $* *$ & $* *$ & $* *$ & $* *$ \\
\hline L.S.D. 5\% & 75 & 1.15 & 0.32 & 0.57 & 96.14 & 95.20 \\
\hline \multicolumn{7}{|l|}{ Cultivars (C) } \\
\hline Brands & 897 & 25.10 & 7.49 & 11.47 & 846.7 & 848.7 \\
\hline Dale & 945 & 25.89 & 7.94 & 12.96 & 840.0 & 970.2 \\
\hline Honey & 759 & 21.86 & 6.20 & 9.83 & 780.3 & 699.1 \\
\hline Leoti & 962 & 25.62 & 7.57 & 12.44 & 1043.4 & 982.0 \\
\hline Planter & 897 & 23.89 & 7.10 & 11.58 & 1001.3 & 875.4 \\
\hline Rex & 980 & 25.82 & 7.69 & 12.81 & 857.0 & 876.8 \\
\hline Rio & 1139 & 27.47 & 8.91 & 13.04 & 1095.9 & 1022.7 \\
\hline Tracy & 862 & 23.06 & 6.88 & 10.95 & 782.1 & 803.4 \\
\hline Umbrella & 835 & 22.24 & 6.54 & 10.75 & 830.9 & 734.9 \\
\hline Williams & 994 & 25.82 & 7.93 & 12.62 & 881.9 & 939.0 \\
\hline Sign. & $* *$ & $* *$ & N.S & $* *$ & $* *$ & $* *$ \\
\hline L.S.D. 5\% & 92 & 2.31 & - & 0.71 & 28.7 & 93.2 \\
\hline \multicolumn{7}{|l|}{ Interactions } \\
\hline YxS & $* *$ & N.S & N.S & $*$ & $*$ & $*$ \\
\hline YxC & $* *$ & $* *$ & N.S & $*$ & $* *$ & $*$ \\
\hline $\mathrm{SxC}$ & $* *$ & $* *$ & N.S & $* *$ & $* *$ & $*$ \\
\hline $\mathrm{YxSxC}$ & $* *$ & $* *$ & N.S & $* *$ & $* *$ & $*$ \\
\hline
\end{tabular}

Regarding the effect of cultivars on forage yield/ fed., combined results demonstrated that cultivars insignificantly differed in forage yield. Rio cultivar yielded the highest forage yield/fed. (8.91ton) followed by Dale, Williams, Rex and Leoti, while, Honey exhibited the lowest forage yield/fed. (6.20ton) followed by Umbrella and Tracy. These findings are agree with those of Besheit et al.(1996); Abd El -Karim et al. (1999) and Besheit and Mekdad (2016).

The first and second order interaction significantly affected average stripped stalk weight/ plant and stripped stalk yield/ fed., however forage yield showed vice versa trend (Table 3).

\subsubsection{Juice and Syrup yields}

Results in Table (3) indicated that juice and syrup yields gradually and significantly diminished as sowing date delayed to reach the minimum level at July sowing. Further, both traits were significantly higher at 2018 season as compared with 2017 season (Table 3). The reduction in both traits may be greatly related the effect of sowing dates on juice extraction \%; stripped stalk yield and total soluble solids as mentioned before. These results are corroborate 
those of Besheit et al. (1996) and Al-Labbody et al. (2008).

Sorghum cultivars significantly affected syrup yield as shown in both combined results (Table 3) and other years (not presented). Juice and syrup yield/ fed. were fluctuated between 9.83 and $13.04 \mathrm{t} / \mathrm{fed}$. and 780.3 to 1095.5 $\mathrm{Kg} / \mathrm{fed}$. for Honey and Rio, respectively. The variation detected among the tested cultivars for both traits were markedly relates to JEP, SEP, stripped stalk yield and quality traits in addition to the tolerance and susceptibility of the used cultivars to pink stem borer and corn leaf aphids which measure by many constant parameters as discussed previously. These findings are in harmony with those of Mahmoud et al. (2013), El-Geddawy, et al. (2014) and Amer and Besheit (2016) who reported that sorghum cultivars potentiality varied greatly in juice and syrup yields.

\subsubsection{Ethanol yield}

Ethanol or bio-ethanol or bio-fuel is very important due to its utilization as natural source of free octane fuel beside its implement in other purposes. Therefore, use of agricultural resources rich and available carbohydrates could be easy fermented to ethanol production. Nevertheless, sweet sorghum juice, bagasse and grain could be used in implement this goal. The theoretical ethanol yield (EtOH) could be calculated according to Smith and Buxton (1993). In this connection,the present combined data (Table 3) illustrated that sowing dates on May and April maximized ethanol production /fed., with delaying sowing ethanol production gradually decreased to reach the minimum corresponding to July sowing. This tendency is correlated greatly to the total fermentable sugars (sucrose + reducing sugars) and juice yield accompanied to sowing dates. Al-Labbody et al. (2008) stated that early sowing increase the quantity of ethanol produced as compared with late sowing.

Ethanol yield/ fed. exhibited significant differences among sorghum cultivars in combined results across 2017 and 2018 seasons (Table 3) and other years (not presented). Ethanol yield ranged between $699.1 \mathrm{~L} / \mathrm{F}$ for Honey cultivar and 1022.7 L/F for Rio cultivar. Six cultivars yielded more than their average 875.5 L/F. Such effect gives evidence that most cultivars under study had high efficiency in producing ethanol. Kresovieh and Henderlong (1984) reported the feasibility of sorghum for ethanol production. Moreover, Smith and
Buxton (1993) stated that sweet sorghum juice was a good substrate for ethanol production. Furthermore, the variations among sweet sorghum ability in ethanol production detected in this work were affirmed by Allam et al.(2001), Al-Labbody et al. (2008) and Besheit and Mekdad (2016).

The first and second interaction degree (Table 3) significantly affected ethanol yield production. Such effect gives evidence that ethanol production is greatly affected by both the used factors meantime may be due to the effect of juice quantity and quality on this trait

\section{REFERENCES}

Abdel-Gawad K.I. (1981). Studies on some factors influencing the productivity of summer fodder crop (Sorghum bicolor (L.) Monesh). Ph.D. Thesis, Fac. Agric. Cairo Univ. Egypt.

Abd El-Karim H.A, El-Ammari T.S. and Maria Beshay G. (1999). Evaluation of some sweet sorghum cultivars for syrup and biomass production J. Agric. Sci. Mansoura Univ., 24 (10): 5285 - 5295.

Abd El-Razek A.M., Besheit R.S. and ElSogheir K.S. (2014). Yield and quality and susceptibility of Egyptian new candidate sugarcane to insect pests. Inter. conf. : 2014 Green Technologies for sustainable growth of sugar \& Integrated Industries in Developing countries Nov.,25-28, 2014.

Al-Labbody A.H.S., Abd El- Razek A.M. and Besheit S.Y. (2008). Evaluation of some sweet sorghum varieties (Sorghum bicolor L. Moench) under two sowing dates. Zagazig J. Agric. Res., 35(1):1- 18.

Allam S.M., Nassar A.M., Abo-El-Wafa A.M. and Ali M.K. (2001). Quality and processing evaluation of some sweet sorghum varieties and their potentialities for syrup and ethanol production. J. Agric. Sci. Mansoura Univ., 26 (1): 1-12.

Almodares A., Sepahi A. and Karve A. (1994). Effect of planting date on yield and sugar production of sweet sorghum. Ann. Plant Physiol., 8: 49-54.

Almodares A., Jafarinia M. and Hadi M.R. (2009). The effects of nitrogen fertilizer on chemical compositions in corn and sweet sorghum. American-Eurasian J. Agric. and Environ. Sci., 6 (4): 441-44.

Aly M.H. and Besheit R.S. (2014). Effect of bio-fertilization on productivity, quality 
and aphids infestation in stevia (Stevia rebaudiana Bertoni). Egypt. J. of Appl. Sci., 29 (7): 319-336.

Aman S., M.M. (2010). Effect of nitrogen fertilization and time of harvest on chemical composition of sweet sorghum. M. Sc. Thesis, Fac. Animal Production, Al-Khartoum Univ., Al-Sudan, 33 p.

Amer E.A.M. and Besheit R.S. (2016). Evaluation of productivity, quality and pink stem borer resistance in sweet sorghum genotypes. Egypt. J. Plant Breed., 20 (3): 625-638.

Amin A.H., Draz K.A., Soliman Kh. A. and Tabikha R.M. (2013). Genetic fingerprints and phylogenetic relationships of eighteen aphid species from Egypt (Hemiptera: Sternorrhyncha: Aphididae). Munis Entomol.\& Zool., 8 (1): 387-406.

Audilakshmi S., Mall A.K., Swarnalatha M. and Seetharama N. (2010). Inheritance of sugar concentration in stalk (brix), sucrose content, stalk and juice yield in sorghum. Biomass Bioenerg., 34: 813820.

Besheit R.S. and Mekdad A.A. (2016). Effect of nitrogen fertilization on the productivity and sensitivity of two sweet sorghum varieties to Pink Stem Borer (Sesamia cretica led.) infestation. Assiut J. Agric. Sci., 47 (6-1):1-17.

Besheit S.Y., Dooh A.A., Maria Beshay G. and Ali M.K. (1996). Stalk and influenced by nitrogen fertilization. Adv. Agric. Res., 1: 36-42.

Besheit S.Y., El-Ammari T. S., Maria Beshay G., Abd El -Karim H. H. and Allam S.M. (2000). Juice quality, processing parameters and potentiality of five sweet sorghum cultivars under three locations in Egypt. Egypt. j. Appl. Sci.,15 (6) : 94106.

Blackman R.L. and Eastop V. S. (2000). Aphids on the world's crops: An Identification and Information Guide (text book). Wiley\& Sons, New York ,USA, 413 pp.

Djodda J., Nukenine E.N., Ngassam P. and Yougouda H. (2013). Degree of infestation of transplanted sorghum [Sorghum bicolor (L) Moench] by Lepidoptera stems borers and their biodiversity in Diamaré (Maroua, Cameroon). Amer. Open J. Agric. Res., 1(1):1-7.
El-Geddawy D. I.H., Awad N.M.M. and Sahar Moustafa M.I. (2014). Lighting spot around yield and technological characteristics of some sweet sorghum varieties. Int 1 l. J. Curr. Microbiol. App. Sci., 3(4): 843-850.

El-Rawy A.M., Mourad A.E.A.A. and EL-Kady A.M. (2013). Evaluation of some grain sorghum lines for resistance to Sesamia cretica Led. and yield potential. Egypt. J. Agric. Res., 91 (3): 977-989.

Galal A.A., El-Shenawy A.A. and Amer E.A. (2002). Additive, dominance, and epistatic effects controlling resistance to Sesamia cretica led. in maize.

Minufiya J. Agric. Res., Minufiya Univ., Egypt, 27: 1209-1215.

Gomez K.A. and Gomez A.A. (1984). Statistical procedures for agricultural research (2 ed.). John Wiley and sons, New York,USA, 680p.

Helmi A. and Rashwan R. (2013). Effect of wheat cultivars and sown dates of aphid infestation in Egypt. Munis Entomol. \& Zool., 8 (2): 825-830.

Kresovieh S. and Henderlong P.R. (1984). Agronomic potential of sorghum as raw material for ethanol production in central Ohio. Energy Agric., 3: 145-153.

Maareg M.F., Abu-Dooh A.M. and Ebieda A.M. (1993). Varietal resistance to purple - lined borer Chilo agamemnon Bles. and relative differential yield loss of certain local sugarcane varieties in Egypt. Annals of Agric. Sci., Moshtohor, 31(1): 517527.

Mahmoud E.A., Ramadan B.S.H., Bekheet M.A. and Gomaa M.A. (2013). Effect of nitrogen fertilization and plant density on productivity and quality of sweet sorghum. American-Eurasian J. Agric. and Environ. Sci., 13 (5): 654-659.

Mailafiya D. M. and Degri M.M. (2012). Stem borer's species composition, abundance and infestation on maize and millet in Maiduguri, Nigeria. Arch. Phytopath. and Plant Protect., 45 (11):1286-1291.

Meade G.P. and Chen J.C.P. (1977). Sugarcan Handbook, 10th edition. Wiley InterScience, Publication, New York, pp. 405.

Munson R.E., Schaffer J.A. and Palm A.W. (1993). Sorghum aphid pest management. http// extension2.missouri.edu/g4349

Nuessly G.S., Wangi Y., Sandhu H., Larsen N. and Cherry R.H. (2013). Entomologic and 
agronomic evaluation of 18 sweet sorghum cultivars for biofuel in Florida. Florida Entomol., 96 (2): 512-528.

Salman A.M.A., Abazied A.A. and Fahmy A.M. (2014). Effect of some cultural practices on the infestation level of Chilo agamemnon Bles., infesting sugarcane varieties at Luxor Governorate. Middle East J. Agric. Res., 3(3): 569-575.

Shoemaker C.E. and Bransby D.I. (2010). The role of sorghum as a bioenergy feedstock. Sustainable Alternative Fuel Feedstock Opportunities, Challenges and Roadmaps for Six U.S. Regions,Proceedings of the sustainable for advance biofuels workshop Embassy suites,centennial olympic park, atlanta Georgia, USA. Brain R.D. Karen and Johnson (Eds.): 149-156.

Smith G.A., and Buxton D.R. (1993). Temperate zone sweet sorghum ethanol production potential. Biores..Technol., 43:71-75.

Xin Z. and Wang M.L. (2011). Sorghum as a versatile feedstock for bioenergy production. Biofuels 2: 577- 588 .

\title{
تقييم مقاومة الإصابة بدودة القصب الكبيرة ومنّ أوراق الذرة في أصناف الذرة الذورة السكرية

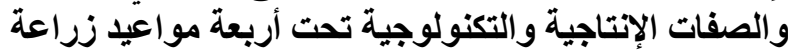

\author{
رامى سمير بشيث - سمرعبد العاطى محمد حلمى - سعيد مصطقى ابراهيم بقوش \\ معهد بحوث المحاصيل السكرية- مركز البحوث الزر اعية- جيزة ـ مصر.
}

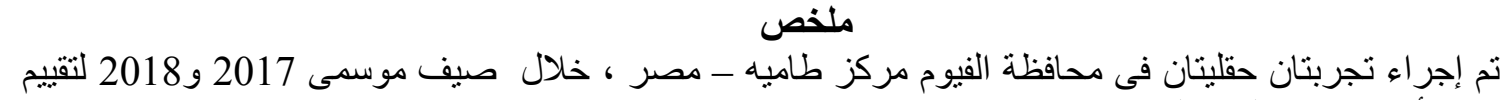

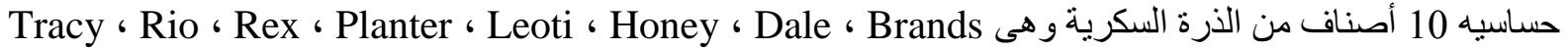

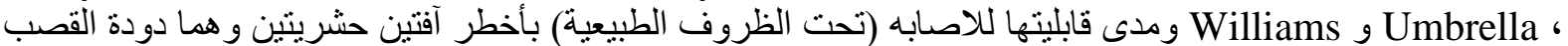

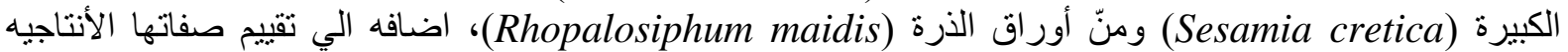

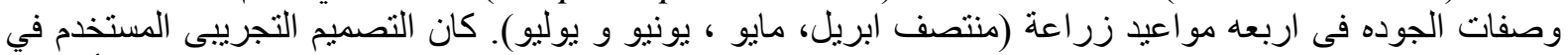

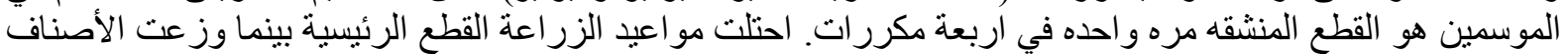

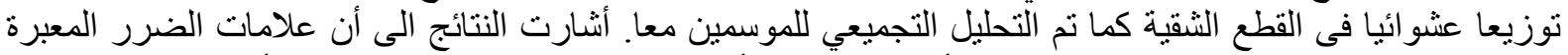

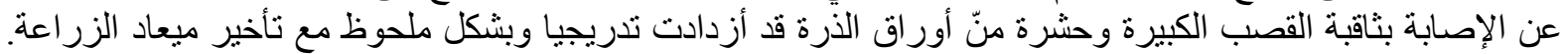

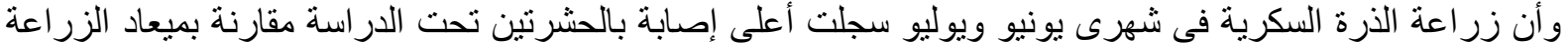

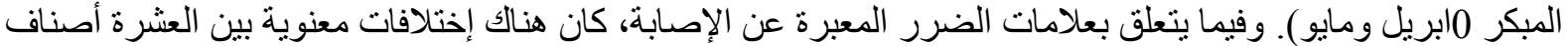

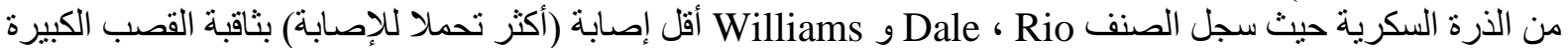

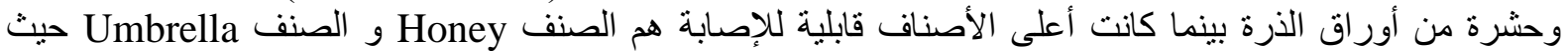

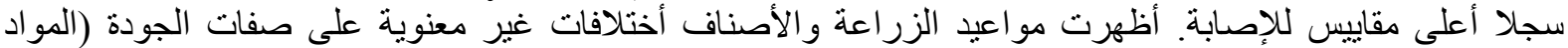

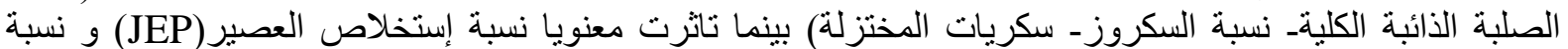

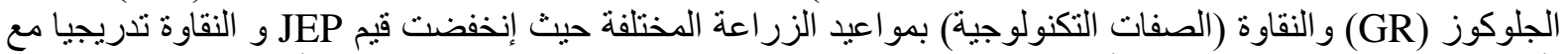

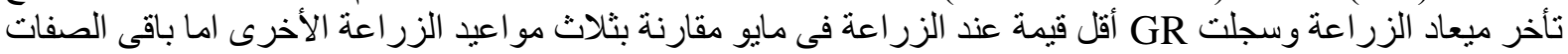

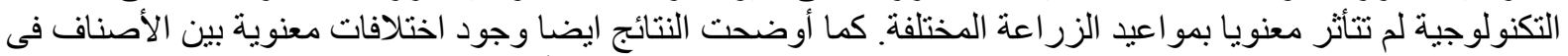

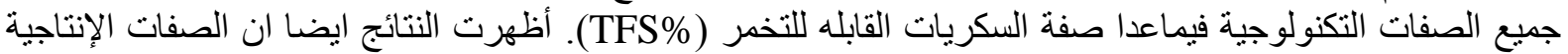

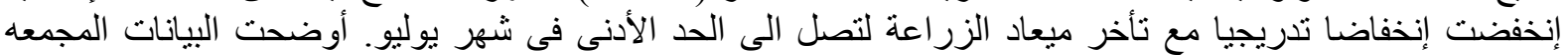

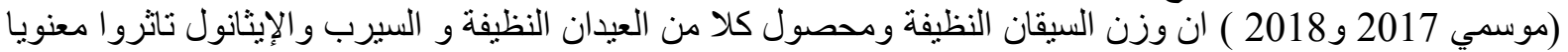

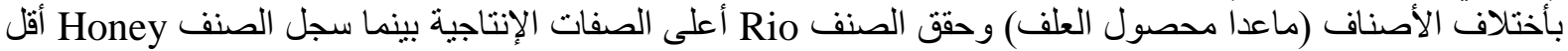

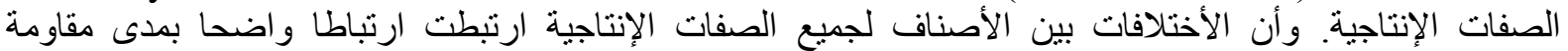

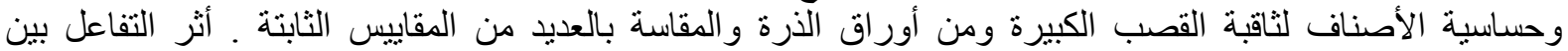

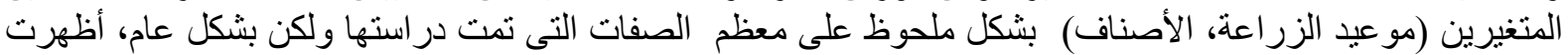

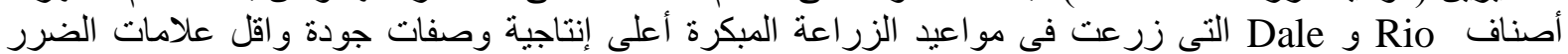

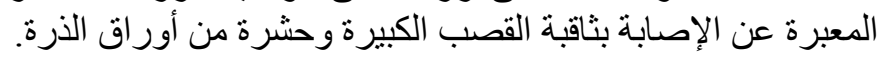

